\title{
Hermeneutics in Contemporary Turkey: An Analysis of Turkish Historicists
}

\author{
Gokhan Bacik (iD)
}

Citation: Bacik, Gokhan. 2021. Hermeneutics in Contemporary Turkey: An Analysis of Turkish Historicists. Religions 12: 1027. https://doi.org/10.3390/ rel12111027

Academic Editors: Ismail Albayrak and Hakan Coruh

Received: 23 September 2021 Accepted: 16 November 2021 Published: 22 November 2021

Publisher's Note: MDPI stays neutral with regard to jurisdictional claims in published maps and institutional affiliations.

Copyright: (C) 2021 by the author. Licensee MDPI, Basel, Switzerland. This article is an open access article distributed under the terms and conditions of the Creative Commons Attribution (CC BY) license (https:// creativecommons.org/licenses/by/ $4.0 /)$.
Department of Politics and European Studies, Palacký University, 77900 Olomouc, Czech Republic; gokhan.bacik@upol.cz

\begin{abstract}
The hermeneutical turn in Islamic studies has also affected Islamic scholarship in Turkey, a country where traditional Sunnism historically dominates. Historicism in Islamic studies became an influential intellectual and academic current in Turkey after the 1990s. This was mostly because the first generation of Turkish scholars, who associated themselves with historicism through complex engagement with Quranic hermeneutics in their studies, emerged in the 1990s. In this article, I analyze Mustafa Öztürk, İlhami Güler, and Ömer Özsoy, the architects of the historicist turn of the 1990s in Turkey who are still prominent. The article explains: (i) The Turkish historicists' views on the nature of the Quran; (ii) Their hermeneutical approach in interpreting the Quran; and (iii) Illustrates how they apply the hermeneutical approach to the interpretation of the Quran by presenting how they interpret the Quran's relevant verses on corporal punishment/chopping and divorce. The article aims to detail historicism in Turkey by studying its leading scholars.
\end{abstract}

Keywords: hermeneutics in Turkey; Turkish historicists

\section{Introduction}

The hermeneutical turn in Islamic studies has also affected Islamic scholarship in Turkey, a country where traditional Sunnism historically dominates. In 1979, Fazlur Rahman, the pioneering name in historicism, visited Turkey and exchanged opinions with the academics of Ankara University's Faculty of Theology. However, historicism in Islamic studies became an influential intellectual and academic current in Turkey after the 1990s. This was mostly because the first generation of Turkish scholars, who associated themselves with historicism through complex engagement with Quranic hermeneutics in their studies, emerged in the 1990s. In this article, I analyze Mustafa Öztürk, İlhami Güler, and Ömer Özsoy (hereafter, the Turkish historicists, or the historicists), the architects of the historicist turn of the 1990s in Turkey who are still prominent. ${ }^{1}$

In what follows, I first explain the Turkish historicists' views on the nature of the Quran. Then, I analyse the Turkish historicists' hermeneutical approach in interpreting the Quran. To further deepen my analysis, and to illustrate how they apply the hermeneutical approach to the interpretation of the Quran, I study how the Turkish historicists interpret the Quran's relevant verses on corporal punishment/chopping and divorce. The article aims to detail historicism in Turkey by studying its leading scholars, a subject on which there is not much work in the global literature.

\section{Turkish Historicists on the Nature of the Quran}

Historicism is a method that insists on the prime importance of the historical context for the interpretation of texts of all kinds (Hamilton 1996). When applied to the study of the Quran, it is de rigueur to interpret the verses with reference to their historical context, the time of the Prophet Muhammad, and of the early Muslims. Historicism recognizes the authentic meaning of a verse (that is, how it was understood in its historical context) as the objective framework for understanding it now (Öztürk 2018a). That the historicist method 
is at all possible is owed to a set of peculiar views on the nature of the Quran. I shall first summarize those views, then explain how the Turkish historicists interpret the Quran.

\subsection{The Quran Has No Divine Nature}

Turkish historicists reject the Quran's divine nature. Instead, it is created, and is, therefore, not eternal (Öztürk 2013; Güler 2017a). In The Mu'tazili Interpretation of Quran, which reminds us of various verses, such as $50 / 38$, which reads as, "we created the heavens, the earth, and everything between", Öztürk (2015a, p. 35) deduces that God could have spoken so only after he had created the earth, which means that the Quran is not eternal. Any argument that proposes that certain verses existed before the creation of the earth is committed to the conclusion that God made a claim that something that happened did not, in fact, happen. ${ }^{2}$ That, of course, is not in harmony with the nature of the deity.

The "createdness" thesis is the foundational principle of historicism that proposes the hermeneutical method for interpreting the Quran. Importantly, Turkish historicists depart from the Sunni view of the Quran's nature by embracing the thesis attributed to the Mu'tazila. Güler (2017b, p. 28) correctly asserts that Sunnis would brand them with the label "heretics". In Sunnism, the Quran is not created; it is divine and eternal. The Quran is the Word of God in meaning and style (Öztürk 2018b). The origin of the Sunni dogma is the theological opinion promoted by Ash'arism and Maturidism, the two major schools of Sunni theology. Accordingly, God's attributes, including his kalam (speech), are divine (al-Ash'ari 1940; al-Maturidi 2018). The logical conclusion is the Quran's divinity, since it is God's speech (Güler 2017c; Öztürk 2013). In contrast, the Mu'tazila School accepts the "created Quran" tenet, and rejects its divinity, and the "God's speech" canon (Öztürk 2014).

A soft version of the Sunni dogma emerged later, arguing that there is an eternal Quran in heaven (kalam nafsi), and another in this world (kalam lafdzi) (Larkin 1998). The soft theory was advanced by Ibn Kullab (d. 854) as a compromising formula during the Mihna (Melchert 1997). The Mihna was introduced by the Abbasid caliph, al-Ma'mun (d. 833), to enforce the doctrine of the createdness of the Quran. However, it eventually failed because of the resistance of traditional scholars. Caliph al-Mutawakkil (d. 861) abandoned it altogether (Nawas 1996). However, Turkish historicists see the soft theory as a tactical attempt to challenge the Mu'tazili view (Öztürk 2018a). Thus, they reject the heavenly Quran as well (Öztürk 2013; Güler 2017c). Öztürk (2016a) dismisses the soft theory as a theological metaphor that brought no real change. He observes that Muslims are still loyal to the traditional Sunni dogma of the divine Quran.

Attributing a divine nature to the Quran is, therefore, rigorously criticized by Turkish historicists. Lambasting Sunnis for proclaiming the Quran a God-like divinity, Güler (2017c) condemns it as an idolatry. Inspired by Naser Abu-Zayd, Öztürk (2016a) finds the uncreated Quran incompatible with Islam, where a major commandment is to reject the dual nature of Jesus. Beyond the theological reservations, the intellectual legacy of the divine Quran is also bothersome for Turkish historicists, who consider it a major obstacle, one that permanently undermines rationalism in Islamic thought (Güler 2017c). Öztürk (2016a) describes the uncreated Quran as a boundary within Islamic thought that is an impasse, which puts human reason out of reach. Likening it to the Sunni "end of history" thesis, Güler (2011, p. 37) holds that the Sunni dogma is responsible for the popular belief among Muslims in a divine resource with perfect solutions to everything. Therefore, historicists see the rejection of the divine Quran as the essential prerequisite of a rationalist turn in the Islamic tradition.

\subsection{The Quran Is Historical}

In Sunnism, the Quran is an ahistorical message sent to this world by divine intervention (al-Ghazali 1977; Karaman et al. 2012; Öztürk 2018a; Neuwirth 2010). Thus, no historical event affected the formation of the Quran; it does not belong to this world (Öztürk and Ünsal 2018; Güler 2018a). The opposite is true for the historicists: the Quran is historical and was determined by historical dynamics. The Quran belongs to this world 
(Öztürk 2013; Güler 2017c). Özsoy (2004) summarizes the historicist principle: There is no ahistorical thing at the human level; everything is part of history, and everything is subject to natural causation, including the Quran.

For historicists, social and political developments in Mecca and Medina affected the Quran at all levels, including the content of its verses. Öztürk (2018a) illustrates this by analyzing the changing attitude towards Jews in the Quran. Accordingly, though earlier verses revealed in Mecca, such as 21/7, 10/94, and 16/43, cite Jews in amicable terms, later verses, revealed in Medina, view them bitterly because of the changing political status quo. For example, when Muslims, who were yet a small group, needed their support in Mecca, verse 10/94 mentions Jews affirmatively, as a reference group: "So if you are in doubt about what we have revealed to you, ask those who have been reading the scriptures before you." However, once the Muslims got a grip on power in Medina, the tone of the revelations towards the Jews changed, and turned into a humiliating depiction in "Surah al-Baqara". Verse 2/120 speaks against Christians and Jews, for they are never pleased unless Muslims follow their ways. Moreover, while the earlier verses identify Abraham as a Jew, the Medina verses portray him as a hanif (monotheist). Öztürk (2018a, p. 113) asserts that the impact of the tense political atmosphere between Muslims and Jews caused contradictions, even in the Quran's verses. He points out verse 9/29, which describes Jews as the People of the Book who do not believe in God, and reads it as an oxymoron, for Jews cannot not believe in God while they are the People of the Book. In another example, Öztürk (2018c, pp. 193-208) expounds upon how economic dynamics affected the revelation: when non-Muslims were prohibited from approaching Ka'ba (9/28), it sparked complaints among Muslims, for it caused them economic losses. Responding to them, verse 9/29 then introduced jizyah, a per capita yearly taxation levied on non-Muslims, and even asked Muslims to fight them "until they pay the taxes." Such cases, for Öztürk (2018a), prove how historical developments determined the revelations. Otherwise, the only explanation would be to accept that God changed his mind, a contradiction of His deity. In like manner, the revelations' responses to historical conjunctures also falsify the concept of an eternal fixed-content Quran.

The "Historical Quran" also requires key Islamic concepts, cited in the verses as determined in history by the surrounding milieu and culture. Thus, the meanings of the key terms, regarded as the foundation of Islamic faith, have no eternally set meanings. For example, Güler (2018a) presents God in the Quran as a heavily anthropomorphic conceptualization, reflecting the Arab mindset. Similarly, Özsoy (2004, p. 17) explains how various divine attributes, such as muntaqim (revenge taker), reflect the 7th-century Arab understanding of the deity. Having such facts in mind, Güler (2018a, p. 79) concludes that the Quranic God is a reflection of the Arab mentality, where He is imaged as a just King who has a master-slave relationship with people. Quoting R. E. Emerson's, "the god of warriors is a warrior, the god of tradesmen is a tradesman", Güler (2018a) deduces that the God of the Quran is a reflection of Arab culture. Güler (2018b, p. 181) does not then hesitate to warn that the Quranic God, having emerged in a specific social and historical context, might be unsatisfactory for later times or other cultures. In practice, this is to accept that the concept of God in the Quran is not a universal one. Historicists re-use this argument for other critical purposes. Öztürk (2013, p. 211) detects shirk (polytheism), a term used in the Quran in the context of an early Muslim society. That word does not speak for a universal perspective. It cannot be imagined to be referencing other practices, such as the Iranian worship of fire. In general, Güler (2017a) observes that the religious vocabulary of the Quran has no reference to distant religions, such as Hinduism or Shamanism. As a consequence, even key concepts of the Quran are historical in the sense that their meanings were determined by the social and political dynamics of their time and location. To illustrate the complicated interaction of the Quran and its historical context, Güler (2015a) likens it to the relationship of British pragmatism and the 18th century industrial revolution, and to how Immanuel Kant was linked to the politics of the Prussian Empire. As in those contexts, the Quran cannot be abstracted from 7th-century Arab life and culture. Similarly, 
there is an Arab anthropological shadow on the Quran (Güler 2016a). This is normal for Öztürk (2018c), since the Quran was also exposed to the social, and other, dynamics of its society, such as any other historical phenomenon.

\subsection{The Quran and Universalism}

Not seeing the Quran as universal, historicists define it as having a local scope, limited by the Arab life around Mecca and Medina in the 7th century (Güler 2016a). Accordingly, the Quran addresses only those Arabs who were in conversation with Muhammad (Güler 2018a; Öztürk 2016b; Özsoy 2017). Therefore, the Quran gives its universal messages through local people and events in a 7th-century Arab context. Thus, the Quran is a local interpretation of the universal message for historicists (Özsoy 2004; Güler 2017a). Logically, for historicists, other people in different times and places are not addressed by the Quran (Özsoy 2004; Öztürk 2013). The Quran is, therefore, not in dialogue with all ages. Güler (2017b, p. 27) clarifies this by defining the Quran as a collection of speeches that happened only "in Arab society, and on the Arab street." Thus, it belongs to a specific time and geography (Öztürk 2013).

In this regard, expressions in the Quran, such as "O, you people", are not interpreted as addressing all humanity. Accordingly, such utterances are like the politician's opening words to his audience, even in a small village: "Dear citizens ... ". That politician is not understood to be addressing all of the people in the country. In a similar fashion, the Quran speech is local; hence, it cannot be imagined to be, for example, addressing today's Turkish people. Thus, direct discourses in the Quran, such as "O, you ... ", address only those who lived with Muhammad, including the polytheists, Muslims, and Christians (Öztürk 2016a; Özsoy 2017). Paul Ricoeur's approach might be helpful for a better view of the historicists. Ricoeur $(1976$, pp. 13,31) categorizes pronouns in a conversation as having no objective or universal meaning. Thus, a pronoun-such as they or you-has "meaning each time it is used, and each time it refers to a singular subject. Thus, we need to know whom it addresses in each conversation. However, writing gives way to a "universalization of the audience." If we are not informed about the background, we tend to read a text as universal speech, addressing anyone who reads it. However, by not defining the Quran as a universal text, historicists interpret each you in the Quran in terms of its singular subject in its historical context, which is Mecca and Medina during the prophethood of Muhammad.

The locality of the Quran is not only a case of pronouns; the verses in the Quran are meaningful only in their local context for historicists (Öztürk 2013). In other words, they do not have universal meanings independent of their local contexts. The logical result of this reasoning is more important: Treating the Quran as if it was a universal book would inevitably lead to the wrong conclusions, such as recognizing the local elements in the Quran as universal norms. Özsoy $(2004$, p. 14) gives an example to demonstrate this problem: The literature is full of the virtues of breastfeeding a baby for two years. Yet this abstraction is the result of a false interpretation of verse (2/133), which reads as, "mothers suckle their children for two whole years." In reality, the verse informs us about an Arab tradition that has nothing to do with a universal health principle (Öztürk 2017a, p. 21). Similarly, many verses (such as $17 / 11,18 / 54$, and $80 / 17$ ) that define "human" as a very negative property are read as if they are axiomatic statements about human nature. However, Öztürk (2017b, p. 81) warns that those verses address some people who lived during Muhammad's time. However, in missing the significance of that contextual element, those local verses are read as if the Quran presents a very negative view of human nature. As the misinterpretation of the above verse illustrates, Öztürk notes that reading all verses as if they have universal content leads to another big problem: recognizing every verse as being equally a source of Islamic law. In fact, the Quran has verses that cannot be thought to enunciate universal truths. As Öztürk (2018c, pp. 185, 270-71) believes, it is not logical to imagine God, "the creator of billions of galaxies", providing a universal message through person-specific verses, such as 33/53, where a group of companions are asked to not talk long at Muhammad's home during a wedding, or verse 33/51, which regulates 
the nightly frequencies of Muhammad's being with his wives. Güler (2017c, p. 108; 2018a, p. 58) also sees those verses about Muhammad's private life as having only local content, not universal messages. Even for him, they could trigger faith problems among Muslims if not well-framed within a historicist logic.

For the historicists, any concepts in the Quran that are understood to have universal application are, in fact, collected from the local Arab environment (Güler 2016b). For instance, Muslims understand the Paradise of Quran to be a divinely designed portrait of the legitimate universal expectation of the deserving. However, Öztürk (2013, pp. 219-22) remarks on the Quranic Paradise, where rivers flow, as a portrait of desire for Arabs, whose life allotment is the desert. It does not work as a portrait for people who live in countries, such as Bangladesh, where there are frequent floods. Moreover, how the Quran presents a houri, the maiden who awaits Muslims in Paradise, is according to a typical Arabic concept of beauty, dating back to pre-Islamic poets, such as Imru' al-Qais (d. 540). Then there is sidr, the tree that the Quran describes in Paradise, which is also a theme of Arab poets, such as Umayyah ibn Abi Salt (d. 630), who composed similar depictions of Paradise that contain the same tree (Öztürk 2013, pp. 211-20). As a matter of fact, such discussions are known in various classics: Ibn Ishaq (1955, pp. 28-29)—an 8th-century historian-wrote that kawthar, a Quranic term that stands for the miraculous water of Paradise, was used by the poet, Labid (d. 661). Historicists frequently underline that, as the examples of classical authors' creations demonstrate, the Quran uses concepts familiar to the local Arab mind. Öztürk (2013) explains this as the normal pattern since the vocabulary of the Quran was determined by its local context. These authors remind us that the lists of the names of various things, such as fruits, foods, and many other things in the Quran, are only local examples. As a consequence, for historicists, the meaning of words in the Quran are also not universal. Thus, they are critical of the practice of seeking to understand such words as if they are universal terminologies.

\subsection{The Quran Is Not a Book}

Historicists are against imagining the Quran as a book (Özsoy 2017; Öztürk 2015b; Güler 2017a). Not designed or written as a book, the Quran, in the historicists' view, is a collection of speeches articulated as responses to various events during Muhammad's prophethood (Özsoy 2004). They are also of the opinion that Muhammad had no intention of compiling the revelations into a book format. His goal was to leave a sample community to inspire Muslims (Öztürk 2015c). Historicists opine that what made Muslims imagine the Quran as a book was the compilation of the revelations in book format after Muhammad (Güler 2018a). Imagining the Quran as a book had significant consequences that had a huge impact on the interpretation of Islam. Güler (2017d) observes that historicists are unhappy about the major consequence, which is the invitation to approach the Quran as if it originated as a systematic book on theology. Özsoy (2004, p. 54) says that historicists discern correctly that the "Quran is a book" belief nurtures the popular thinking that a revelation is an external message.

For historicists, the Quran is a collection of speech acts that early Muslims heard and adapted into their practice without imagining them as a systematic text (Öztürk and Ünsal 2018; Öztürk 2018c). Accordingly, the verses were not abstract sentences, but acted-out speeches. William A. Graham's definition (Graham 1977, p. 10), that a revelation is "an activity coextensive with the life of the bearer of revelation, the Prophet", might be explanatory. A revelation is interwoven with action. Inspired by Muhammad Arkoun, Güler (2017c) likewise writes that the Quran is a practical text, not a book of theory. To Güler, the Quran is not like Aristotle's Metaphysics, or Spinoza's Ethica,-—books that construct their messages as abstractions and general principles-but is more like Marx's Capital, a book that gives its messages as practical solutions to the problems of society. Güler's comparison says that the message of the Quran is always delivered through contextual cases. Thus, early Muslims understood the revelations without a need for methodological explanations (Güler 2016c; Öztürk 2013). As proof that early Muslims 
did not regard the revelations as a book, Öztürk (2018a) reminds us that they were never shocked when a new revelation introduced a command that was different from a previous one. He held that there was an ontological relationship between Muslims and the revelation, where the focus was on understanding and practicing, rather than on the search for an epistemic relationship that delivers systematic comprehension. Öztürk (2018c, p. 267) produces this example as a reminder that, despite the verse $9 / 36$ prohibition to wage war during the four special months, Muslims did not interrupt their fights with their enemies. Öztürk (2014, p. 34) also gives an interesting example to demonstrate how the first Muslims were indifferent to the textual and stylistic aspects of the revelations. Accordingly, they were not even alarmed by some formal changes in the transmission of a revelation with changed words. We understand, from the historicist arguments, that the early Muslims did not imagine the revelation as a text. Instead, what mattered to them is what they were told.

For historicists, the Quran's verses are speech acts, the meanings of which are associated with the circumstances in which they were uttered. Güler (2016a) illustrates them as examples of informal communication in a given setting, where people already know the relevant contextual aspects of the speech, such as the emotions it displays. Therefore, as Öztürk (2015b) emphasizes, the meanings of the verses—given that they are speech acts-naturally have a limited connection to the noncontext. In other words, they are not axioms to be understood in a universal context as a modern text. To clarify, by "contextual or complimentary elements of meaning", historicists refer to the standard extralinguistic elements in a speech act, as we read in Searle (1979), that are all relevant to conveying the intentions of the communicator. Özsoy (2004) states that those extralinguistic elements are vital for the correct understanding of a speech act. Similarly, emphasizing that language is not a mechanical transmitter, Öztürk (2017a) defines the interaction of language and its milieu as an essential aspect of communication.

The most important problem for historicists is putting the verses, which were originally speech acts, into book format (Mushaf), despite the fact that they did not come into being as systematic texts. The unavoidable consequence is the various gaps between a speech act and its written form since the latter has no ability to incorporate all the complimentary aspects of the former. There is no perfect match between the meaning a speech act makes and its transcription. Paul Ricoeur (1976) explains this phenomenon as the disappearance of the human facts in "writing up" what someone said. Unlike a speech act, "marks"—words, letters, dots, etc.- convey the message of the text, but at the cost of detaching meaning from the event: "Discourse as event disappears", and we get only a text, which is no longer able to transmit the relationship between the speech and the human context. Thus, for Ricoeur, writing does not fix the event of speaking, but records only what was said of the speaking. This is what Graham (1977) explains as the verbal-noun revelation, which becomes a concrete noun, and refers primarily to a text rather than to a happening (the context). As a consequence, reading the transcription of a speech act is never satisfactory (Smith 2003). Almost repeating Ricoeur, Özsoy (2004) defines a text only as a note on the meaning of the speech act. Öztürk (2015b), too, repeats the perception that the transcription of a speech act is a picture that has lost the meaning-making power of its contextual elements. Özsoy (2004) reminds us that the transition from the speech act to the text may even distort the meaning of the former.

A second, but this time structural, consequence of making a book of the verses (which disturbs the historicists as well) is the Muslim habit of regarding the Quran as if it were sent as a systematic book on epistemology and other subjects (Ö̈zsoy 2004). For Öztürk (2014), the book format of the Quran wrongly became a reference in scholarly studies for interpreting the verses. The historicists' reservation here is about the recognition of the book format, which is a human artifact, as a substantial framework for explaining the verses (Öztürk 2015b). For the historicists, a format that was dictated by people after the revelations should not be taken as if it were the canonical framework for determining how the verses are understood. Özsoy $(2004$, p. 57) reminds us that the historical accounting of an event of the revelation does not even provide satisfactory information on the rationale 
of the placement of the verses in the Quran. Similarly, for Öztürk (2016b), the purpose of the compilation of the verses was only to preserve them; hence, the existing format of the Quran cannot be a systematic reference in any way when one is interpreting the verses. As a consequence, reading the Quran as a text has no reasonable explanation, save that the verses were placed between book covers. Taking things one step further, Öztürk (2018a, p. 81) argues that the between-book-covers mistake caused Muslims to imagine the Quran as a "reference text", but not "a purpose and an intention of God." He is clear that the recognition of the Quran as a reference text by Muslims is the result of their historical practice, which is, nonetheless, in contradiction to God's purpose. In other words, apart from the troublesome effects of the book format for understanding the verses, it is also problematic to search for what is Islamic by looking at a reference book, even if it is the Quran. Özsoy (2004, pp. 46, 109-11) holds the same view: "I don't believe that God's intention is to send a reference book. Instead, his intention was to create a sample community that would inspire people."

To summarize: According to historicists, the compilation of the verses into book format created three major problems:

i. The obfuscating gap between the verses as speech acts, and the verses in written format;

ii. The recognition of the book format as the authoritative framework for explaining the verses;

iii. The recognizing of a book, i.e., the Quran, as the main framework for Islamic reasoning. Alternatively, historicists suggest:

i. Interpreting the verses as speech acts;

ii. Not being bound by where the verses are located in the Quran while interpreting them;

iii. Not to accept that Islam recommends the Quran as the reference book in proposing solutions, but, instead, to know that the Quran recommends to Muslims the community model that the Prophet Muhamad and his friends developed by their practices.

If we return to the problems caused by Mushaf, we see that the verses are now read as if their places in the Quran were originally designed to generate a certain methodological importance. However, Öztürk (2015b) reminds us that each verse was revealed in a different context, so their locations in the Quran cannot be taken as the parameters for their understanding. If the verses are originally speech acts, their chronological order would indeed be important. However, historicists also find that information on the chronology of the verses is limited and contested. For example, Öztürk (2016a, pp. 95-100) reminds us that traditions in Sahih, where Aisha-the prophet's wife-gives contradictory information on which verses were revealed first. For historicists, the chronology problem proves that the Quran in book format no longer transmits extralinguistic conditions, such as the time aspects of the revelation (Özsoy 2017; Öztürk 2015b). Moreover, detached from their historical context, the verses appear as equally important passages in the Quran, with some sort of capacity to affect Islamic law (Özsoy 2004). On the other hand, for the historicists, these are not only theoretical discussions. Their negative impact is also observed among Muslims since they are intra-Muslim conflict makers. Reading the verses without reference to their historical context, which, for historicists, is a frameless interpretation, Muslims may find themselves justifying absurd or radical conclusions. Özsoy (2017) observes that, though it was easily understood by the early Muslims, the Quran became the source of disagreements among Muslims after its compilation in book format during the reign of Caliph Uthman. Simply, for historicists, embracing the revelations in book format triggered the chaos dynamic among Muslims. Öztürk (2018a) reflects that the compilation of the Quran into book format has historically increased conflicts among Muslims rather than decreased them.

For historicists, it is virtually impossible to generate a consistent text by compiling speech acts (Öztürk and Ünsal 2018; Güler 2018a; Özsoy 2004). Logically, they find a 
number of problems in the Quranic text. Özsoy $(2004$, p. 47) lists several structural and stylistic problems in the Quran:

"There are contradictions and redundancies in Quran. It is not possible to discern the logic in the composition of the text; it does not have a chronological or a topical order. The whole text lacks inner consistency, nor is there consistency among the verses: often, even the verses fail to articulate a coherent set of meanings."

Similarly, Öztürk (2016b) lists several problems, such as inconsistency, exaggeration, incoherence, repetition, and contradictions in the Quran, as examples of problems that were brought into being by collecting the verses into book format. According to Öztürk (2015b), there are even single verses that reflect several of these problems. Addressing similar issues, Güler (2016a) does not take the text of the Quran to be systematic in general.

Özsoy (2004) and Öztürk (Öztürk and Ünsal 2018) remind us that they were not the first to detect such problems; even the Sunni literature itself acknowledges many of them. As proof, they present mushkilat al Quran—the difficult issues in the Quran-for which the Sunni scholars provide explanations of the various verses that contain linguistic or other problems. Of course, for Sunni authors of such explanations, what might seem to us to be problems are, in fact, examples of the Quran's $i^{\prime} j a z$, the inimitability of the Quran, which is its miraculous linguistic property (Larkin 1998; Saeh 2015). In addition, historicists present the Sunni theory of nash (the abrogation of a verse by a later verse), as more proof that the Sunni literature is aware of the structural problems in the Quran (Öztürk 2015a; Fatoohi 2013). Nash aims to solve the contradiction among the verses by proclaiming the older verse as abrogated, which is effectively to recognize, and admit to, the presence of contradiction in the text. Another perception of historicists is that nash also demonstrates how Sunni scholars fail to realize that what they are seeing as contradictory verses are, in fact, speech acts that belong to different social contexts (Öztürk 2018c). Accordingly, the verses in the Quran that appear to be contradictory might have had different meanings in their different historical contexts. However, once written, they took on an apparently contradictory property because they lost their contextual uniqueness. Logically, historicists reject as nash what appears to them as contradictory verses in the Quran when they are, in fact, about different subjects in their original contexts.

We encounter examples in the works of historicists of the structural problems in the Quran that have their origin in the compilation of the verses into a book. Typical examples can be read in Öztürk (2015c, p. 121). Accordingly, for example, verse 2/220 has word-order problems, creating serious obstacles to comprehension. ${ }^{3}$ In another example, Öztürk (2015c, p. 121) points to several verses that contradict one another: while verse $55 / 39$ says, "on that Day neither mankind nor jinn will be asked about their sins", verse 37/24 reads, as [God] "halted them for questioning". Moreover, verse 7/6 says, "We shall certainly question those to whom messengers were sent, and We shall question the messengers themselves." To Öztürk (2015b, pp. 19-20), there are also verses that give different information on the same subject: while verse 6/21 reads, "who fabricates a lie against God or denies His revelation" are doing the "greater wrong", verse 18/57 stresses that "who could be more wrong than the person who is reminded of his Lord's messages and turns his back on them." In addition, while verse 58/12 says, "when you come to speak privately with the Messenger, offer something in charity before your conversation", the very next verse, 58/13, declares that no such obligation is imposed (Öztürk and Ünsal 2018, p. 65). As an example of the wrong placement of verses, Öztürk (2015a, p. 107) points to $2 / 226-241$, the divorce verses. Two verses in this paragraph, 2/238-239, are irrelevant, for they are about how to perform salah (five-times prayer) in dangerous situations. Verse 6/119 is another example of a misplacement in the Quran that illustrates how seriously incongruent with its historical-chronological context a misplacement can be. This verse: "God has already fully explained what He has forbidden you," - is about why Muslims should not eat some animals. However, the crux of that prohibition comes 26 verses later, at verse 6/145 (Öztürk and Ünsal 2018, p. 195). From the historicist perspective, the chronological mislocation of verses 6/119 and 6/145 is a typical problem that the book form of the Quran created. 


\section{The Historicist Methodology for Interpreting the Quran}

Having summarized the historicists' views on the nature of the Quran, I shall now analyze their ideas on how to interpret the Quran. In fact, the historicist methodology of interpreting the Quran is a reflection of the historicists' ideas on the nature of the Quran.

Basically, historicists ground their rationale on the historical fact that the verses are speech acts that deliver their messages in the language and life conditions of the 7th-century Arab mindset. This meaning-making mindset was lost when the Quran was given a book format (Güler 2015a; Öztürk 2018a; Özsoy 2004). The solution for historicists is to interpret the verses in reference to their authentic meaning. This entails acquiring a familiarity with how early Muslims understood the verses, in terms of their purpose, context, and social impact (Özsoy 2004; Güler 2017a). The reading of the verses in their authentic meaning is comparable with Searle's $(1969$, p. 35$)$ formulation: " $X$ counts as $Y$ in context $C$ ". If $X$ is the verse as written in the Quran, $Y$ is the authentic meaning. As Güler (2015a) explains, this is done to salvage the nonlinguistic elements of the meanings that are now lost in the written form of the Quran. As we understand it, historicists expect their method to establish "authentic meaning" as the general norm for reading the Quran. This is confirmed by Öztürk (2013, p. 38), who defines "authentic meaning" as God's purpose in revealing a verse. Öztürk's (2018a, pp. 10-15) metaphorical explanation is that the authentic meanings of the verses are the "stem cells" of Islam.

Basically, historicists project the hermeneutics method onto the interpretation of the Quran. Historicists, inspired by various scholars, such as Fazlur Rahman, Nasser AbuZayd, Paul Ricoeur, Friedrich Schleiermacher, Wilhelm Dilthey, and others, believe that it is possible to construct an imagined replica of the historical context in which the early Muslims understood the verses (Öztürk 2013; Güler 2017d). In a nutshell, what matters for them is the principle of hermeneutic analysis, which Ricoeur (1976) defines as the interpretation of a speech act with reference to the analysis of the relationship of the event and its meaning. Thus, as Searle (1979, p. 117) explains, a speech act is never a "zero context" that can be read literally. Instead, it must always be understood with reference to the "background," the historical context in which it was acted out. Similarly, given that the noninstitutional elements of meaning are left in the past, and we are no longer part of that social setting, historicists assert that the best available method is to read the verses in their historical context (Özsoy 2017; Öztürk 2013). The only solution is to employ historical and hermeneutic analyses when interpreting the verses. Özsoy (2004) recommends this as a reliable process for developing empathy with the first Muslims.

There is also another rationale in the historicist method: the historicist concern that interpreting the Quran without an objective framework could result in ultrasubjectivism (Özsoy 2004). Like Abu-Zayd (2010), they are concerned that transferring the verses into the present, thereby disregarding the relationship of the verses to their original contexts, can lead to incalculable misinterpretations. Thus, the historicist position amounts to rejecting the Islamic reasoning of the verses as they are read in the Quran (X). Öztürk (2018a, p. 86) complains that, without an objective framework, the inevitable method is a freewheeling process of reasoning that legitimates "frameless interpretation". And Güler (2016a, p. 247) likens the interpreting of the Quran without reference to the historical context to undisciplined phantasy. For historicists, the danger of frameless interpretation is in the unleashing of anachronic conclusions, or attitudes of fixated presentism (Özsoy 2004; Öztürk 2013). Thus, the historicist method is put to work to search for an objective framework for interpreting the Quran. Accordingly, if there is any context that we can assume to be an objective framework in interpreting the Quran, it is 7th-century Arab society (Güler 2017a; Öztürk 2018a). Özsoy (2004) thus holds that the historicist method is a realistic way of interpreting the Quran. For Öztürk (2018a) too, the historicist method provides a comparatively objective framework for interpreting the verses, and, as Özsoy (2004) notes, it contains the means of fixing the interpretation of the verses inside the boundaries of the historical context. Logically, as Güler (2017a) writes, this would mean that nobody has the authority to impose meanings on the Quran. That cannot be done when there is 
an objective framework that determines the legitimate parameters for extrapolating the meanings of the verses.

When it comes to the practice of their method, historicists, inspired by Fazlur Rahman, suggest a two-level interpretation. On the first level, the authentic meaning of a verse is defined when it is gleaned from a scrutiny of its historical setting (Öztürk 2013). "Authentic meaning", according to Rahman (1982, p. 6), is in the general moral-social objectives of the verses, "distilled" in light of their sociohistorical background. In other words, the historicists take the sociohistorical context of the revelation as their framework, from which the ratio legis will emerge. On the next level, the task is to work out how the authentic meaning of the verse under scrutiny is relevant today (Öztürk 2018c; Rahman 2009). Having identified the general moral-social objective of the verse on the first level, reasoning on the second level pursues the terrain of its applicability in the present-day context. Thus, reasoning on the second level is expected to end with a new ruling. Accordingly, if a law-even when it is literarily prescribed in the Quran-fails to reveal its ratio legis, a new rule can be proposed. Logically, compared to the first level, the second level is more subjective (Öztürk 2018a). Reason is given strong autonomy at the second level in order to discover how the authentic meaning is relevant now. That is tantamount to the enacting of a new ruling (Güler 2015b). For Güler (2017c, pp. 200-1), the objective here is to find out "what God would say to us today", or to "introduce new laws like God". For Özsoy (2004), this is like being a contemporary of Muhammad.

Öztürk (2013) explains that this method does not treat a verse either as a finished or a dead text. Accordingly, when historicists look at a verse $(X)$ in retrospect, they imagine it $(\mathrm{Y})$ as a living phenomenon, still knitted together with events, emotions, and speeches (C). This is what historicists mean by arguing that the Quran is not a book. Instead, they imagine each verse as a living phenomenon in its historical context, along with all its contextual elements. The verse is then imagined similarly in the present, based on authentic meaning. As a consequence, the verse for historicists is not the written form in the Quran $(X)$, but a speech act, along with all its contextual elements, past and present (C, C1). This is what Abu-Zayd (2004, p. 13) dubbed "humanistic hermeneutics", which treats the verses as living phenomena, and "stops reducing the Quran to the status of a text only". Moreover, this is what Fazlur Rahman (1982) saw as the abandoning of the traditional method of reading verses in isolation, without reference to the speech acts that they were upon delivery.

\section{Case Study}

In this part, I shall illustrate how the Turkish historicists interpret the Quranic verses through two cases: corporal punishment/chopping and divorce. This entails us observing their methods at the practical level, going beyond the theoretical discussions.

\subsection{Corporal Punishment: Chopping}

All the major schools of Islamic law, including those of the Shi'a, accept amputation as a punishment for theft (Kamali 2019). The chopping off of hands is practiced in several Muslim countries. The Brunei Penal Code, for example, stipulates the amputation of the right hand for a first offence, and the amputation of the left foot for the second offence. ${ }^{4}$ Radical groups, such as ISIS, practice such methods. For example, Ansar al-Shari’a, in Yemen, chopped off the hands of those accused of stealing (Simcox 2012). In countries where such methods are not practiced, scholars do not rule out corporal punishment. In Turkey, Tefsir-a five-volume exegesis of the Quran prepared for the general public by the Directorate of Religious Affairs-recognizes the chopping off of hands as a legitimate method and provides information on the details, such as how the foot should be amputated (Karaman et al. 2012). Scholarly articles in Turkish that follow the Sunni law continue to report on the details of corporal punishment methods, including hand chopping (Akbulut 2003). 
Corporal punishment in the form of hand chopping has its origin in Verse 5/38, which lays down that Muslims "cut off the hands of thieves, whether they are man or woman, as punishment for what they have done." Treating shari'a as a divine and universal form, Muslims practice what they literally understand from the verse. In Risala, al-Shafi'i (1997) whose view set the Sunni standard—ruled that the punishment, as ordained in the Quran and practiced by the Prophet, is the final one.

Not regarding hand chopping as the cast-in-iron Islamic method, the historicists justify the advancement of alternate punishments. Accordingly, alternate punishments are legitimate if they achieve Islam's higher principles of social order and morality. The historicists rest their reasoning on the principle that Islam makes no higher norm of amputating people's hands, but it does make a norm of establishing a society where people are safe, and where those who would breach the law are deterred by effective rules. Criticizing Sunni scholars for reducing shari'a to a methodology of punishment, Güler (2018d) reminds us that the lesser norms, such as the shari'a rules, may change to realize higher norms. The historicists' stance on the subject reminds us of Fazlur Rahman's $(1965$, p. 239) approach, where the content of penal regulations is "variable," whereas "the universalized principles of good and bad are constant."

On this account, historicists see chopping as the best available practice in the context of 7th-century Arab society. However, chopping hands today proves that the classical methods of Islamic reasoning - satisfactory in the Medieval ages-are no longer effective. The historicists thus propose new methods by reference to the authentic meaning of Verse $5 / 38$. For Öztürk, the punishment verses in the Quran are conjectural regulations that cannot be imagined as fixed principles of Islam to be applied today. They should be understood with reference to their sociological setting. Presenting hand chopping as an Arab cultural method, Öztürk (2018c) draws from Abu Yusuf (d. 767), the leading Hanafite jurist, who spoke of this method as an Arab custom. Similarly, Güler (2020) explains hand chopping as a constant in the economic infrastructure of tribal Arab society; theft was not primarily an economic crime in that tribal Arab society. It was first a crime against tribal honor. Regarding stealing as a direct attack on their tribal honor, the ancient Arabs developed radical punishments, such as chopping. For Güler (2020), theft today is, however, primarily an economic crime that therefore requires different penal responses.

\subsection{Divorce}

Divorce is an all-time controversial topic, as several verses appear to give sole authority to husbands to decide upon a separation. The Muslim practice of divorce in various countries is criticized for not giving equal rights in this matter to women (Subramanian 2008).

The historicists have a different method of justifying their reasoning on divorce. For them, the literal reading of the Quran gives more rights and privileges to men in divorce (Güler 1997). However, they see this as normal, given that the verses on divorce are historical, reflecting the social setting in which the revelation occurred. Admitting that the literal reading of the Quran yields an unequal approach to divorce, the historicists have only one option: to develop solutions by referencing the authentic meaning of the relevant verses. It is possible to analyze the historicist approach to divorce in various ways; however, I limit the discussion to zihar, for it alone is sufficient to demonstrate the gist of the historicist reasoning. Zihar is a pre-Islamic form of separation, whereby the woman is deprived of sexual intimacy, yet she remains a wife. This happened when a man likened his wife to the back of his mother (Nasir 1990; Alekhya 2019). Verse 58/3 rules on zihar:

"Those of you who say such a thing to their wives, then go back on what they have said, must free a slave before the couple may touch one another again--this is what you are commanded to do, and God is fully aware of what you do--but anyone who does not have the means should fast continuously for two months before they touch each other, and anyone unable to do this should feed sixty needy people." 
The practice is still part of Islamic law in various countries. The 168th article of Qatar family law provides that "zihar occurs when a husband compares his wife and/or her body parts to that of another woman forbidden to him to marry." 5 Though not recognized by state law, it is still part of Sunni law in Turkey, too, as Ilmihal-the two-volume catechist book by the Directorate of Religious Affairs prepared for households, mosques, and schools that shapes the popular understanding of Sunni Islam-informs people of extrajudicial forms of divorce, including zihar and talaq (Karaman et al. 1998). As such cases display, Sunni law is adamant about continuing the extrajudicial forms of divorce. Thus, even in countries where the law does not recognize it, relevant rules on zihar are practiced by the customary methods.

The historicists contend that the zihar verses are meaningful only in their historical contexts. Accordingly, the Arabs had many forms of divorce before Islam, and zihar was the worst of them. Finding itself with the acute problems that stem from zihar, Islam was in a position to respond by introducing various rules to protect women. Özsoy (2017, p. 18) explains the regulations on zihar in the Quran as responses to severe problems that women faced in the Meccan society, where zihar was practiced excessively. Thus, the historical context of the verse was the urgent need to respond to problems that had their origins in zihar by introducing heavy penances, such as the freeing of a slave, or fasting for two consecutive months. Thus, the authentic connotation of the zihar verses was not to do with introduction or justification. It had to do with the laying out of strict rules to protect women from its negative consequences. This being the case, Öztürk (2017c) opines that the Quran abolished zihar as a legal form of divorce. Thus, today, a man who wants to divorce his wife should appeal only to the legal forms of the divorce procedure.

To justify their thesis, historicists remind us of the beginning of the Quran's passage, $58 / 1$, on zihar: "God has heard the words of the woman who disputed with you about her husband." This refers to a woman who approaches Muhammad to complain about her husband for his practice of zihar (Öztürk 2017c, p. 51.) From the historicist view, the first Muslims understood those verses-i.e., in their authentic meaning-as new Islamic rules to end the previous practices, where husbands had near-absolute rights and practiced them at the expense of their wives. Reading those verses literally today, without reference to their historical context, however, misleads Muslims into thinking that the Quran recognizes zihar as a universal divorce model. For the historicists, therefore, the zihar case is a typical example that demonstrates how the formalization (i.e., writing) of a speech act is problematic and insufficient. The written form of the zihar verses in the Quran have no capacity to transmit the nontextual elements of the revelation. This gives way to the serious problem of approaching those verses as if they were universal rules. If we visualize the historicist approach to zihar according to Searle's framework (discussed above), we get the illustration in Table 1.

Table 1. The literal and the historicist readings of the zihar verses.

\begin{tabular}{cc}
\hline Literal meaning $(X)$ & Quran justifies zihar as a form of divorce \\
\hline Authentic meaning $(C)$ & Quran attempted to stop zihar \\
\hline
\end{tabular}

The problem of Sunnism, according to the historicists, is that it treats the zihar verses as if they had introduced universal rules. Thus, as noted above with reference to various states, in Qatar and Turkey, zihar is today recognized by their Muslim societies as a universal Islamic regulation. For the historicists, such cases illustrate how a verse that was revealed to fight zihar became, ironically, a verse to justify it. The root of this problematic situation, according to the historicists, is the reading of these verses, revealed in the responses to various problems in the 7 th century, as if they were abstract universal principles. As a consequence, the practice of zihar as a universal model in other cases, for example, in Turkey, where the social setting is completely different, is wrong to the historicists (Özsoy 2017).

The historicist approach to extrajudicial forms of divorce, such as talaq, is the same. Understanding them as historical practices, historicists justify their annulment, or propose 
their displacement, by completely new forms, in terms of the needs of the various social contexts and their times. Thus, for the historicists, if the society has the relevant setting, such as the Western legal regime of divorce, then that might be the model for achieving the Islamic purpose. Öztürk (2018d) reminds us that the historicist principle is to consider the models in the Quran as the best historical practices derived from Arab customs. They are not universal regulations, but responses to local problems. Sharing that view, Güler (1997, p. 318) adds that the reason for the authority given to men in the Islamic divorce mode had to do with the social and economic dynamics that prevailed in early Muslim society. That is, the revelation searched for solutions within the realities of the contemporary society. Güler (1997) notes that egalitarian models would have had no effect in that society, where women had almost no economic independence. On that reasoning, the historicists justify new divorce rules that reflect the contemporary needs of women, so long as those rules pursue the authentic meanings of the verses.

\section{Conclusions}

The findings of this article suggest that Quranic hermeneutics, as applied by the Turkish historicists, yields the critical result of imagining shari'a as a historical and local interpretation of Islam (Güler 2018d; Özsoy 2004). The Turkish historicists see the content of shari'a as collected mostly from 7th-century Arab laws and rituals, not as a universal form. They explain the formation of Islamic shari'a from Arab culture as an example of natural law, where a legal system picks up from the various practices known to people. Thus, all Quranic legal regulations have a pre-Islamic origin. Therefore, Islamic methods, such as the chopping off of hands, or the condoning of polygamy, are not authentic, since they were collected from pre-Islamic Arab culture (Öztürk 2017a, 2017b, 2019). This is natural, as a universal religion necessarily conveys its message in the context of a culture and a society. It is illogical to imagine Muhammad as the Prophet who asked his community to practice a shari'a that is unknown to them (Güler 2016b, 2018a).

Thus, the historicists identify Islamic law, as formulated in the Quran, as a local temporary law. In other words, that law is not universally binding for all times and societies (Öztürk 2018b; Özsoy 2004). There are Quranic laws that clearly cannot be applied universally or literally (Öztürk 2018a). This is to perceive shari'a as only a collection of first samples, not as the final model. For the historicists, equating Islam and shari'a is, therefore, simply to treat the various practices of the Arab historical milieu as if they are universal norms (Güler 2018c; Öztürk 2014). Shari'a was an ideal law only for the Muslims who lived in the 7th century (Güler 2017a). In so doing, the Turkish historicists lead to a radical conclusion about shari'a, that is, to accept the right of succeeding generations to change shari'a rules according to their realities. If the existing shari'a rules are not achieving the high principles of Islam, such as justice, they can be changed.

Funding: This research received no external funding.

Institutional Review Board Statement: Not applicable.

Informed Consent Statement: Not applicable.

Data Availability Statement: Not applicable.

Conflicts of Interest: The author declares no conflict of interest.

\section{Notes}

1 Ömer Özsoy (born in 1963) received his doctorate from Ankara University, the Faculty of Theology, in 1991. Özsoy is now a professor of theology at Goethe University in Germany. Mustafa Öztürk (born in 1965) received his doctorate from Samsun Ondokuz Mayıs University, the Faculty of Theology. He is now a visiting scholar at Munster Wilhelm University in Germany. İlhami Güler (born in 1959) received his doctorate from Ankara University's Faculty of Theology in 1992. Güler continues his studies at the Ankara University Faculty of Theology.

2 In the translations of Quranic verses, I use M. A. S. Abdel Haleem (2005). 
The verse: "On this world and the next. They ask you about [the property of] orphans ... ", Öztürk here refers to the first short sentence.

4 Brunei Sharia Penal Code Order 2013: http://www.agc.gov.bn/AGC\%20Images/LAWS/GazettePDF/2013/EN/S069.pdf (accessed on: 5 November 2019).

5 See: https://www.ius.uzh.ch/dam/jcr:00000000-74d3-1f02-ffff-ffff87068da3/Law2220062558.pdf (accessed on: 29 October 2019).

\section{References}

Abu-Zayd, Nasr. 2004. Rethinking the Quran: Towards a Humanistic Hermeneutics. Utrecht: Humanistic University Press.

Abu-Zayd, Nasr. 2010. The others in the Quran: A Hermeneutical Approach. Philosophy and Social Criticism 36: 281-94. [CrossRef]

Akbulut, İlhan. 2003. İslam Hukukunda Suçlar ve Cezalar. Ankara Üniversitesi Hukuk Fakültesi Dergisi 52: 167-81.

al-Ash'ari, Abu al-Hasan. 1940. Al-Ibanah 'An Usul Ad-Diyanah [The Elucidation of Islam's Foundation]. Translated by Walter C. Klein. New Haven: American Oriental Society.

Alekhya, Somepalli. 2019. Comparative Analysis of Islamic Divorce Laws: Socio-legal Analysis. Journal of Family and Adoption Law 2: 18-26.

al-Ghazali, Abu Hamid. 1977. The Jewels of the Quran: Al-Ghazali's Theory [Kitab Jawahir al-Quran]. Translated by Muhammad Abul Quasem. Kuala Lumpur: University of Malaya Press.

al-Maturidi, Abu Mansur Muhammad. 2018. Kitabü't-Tevhid Açıklamalı Tercüme [Kitab al-Tawhid]. Translated by Bekir Topaloğlu. Ankara: ISAM.

al-Shafi'i, Abu Abdullah Muhammad ibn Idris. 1997. al-Shafi'i's Risala Treatise on the Foundations of Islamic Jurisprudence. Translated by Majid Khadduri. London: The Islamic Text Society.

Fatoohi, Louay. 2013. Abrogation in the Quran and Islamic Law: A Critical Study of the Concept of "Naskh" and Its Impact. London and New York: Routledge.

Graham, William A. 1977. Divine Word and Prophetic Word in Early Islam. Paris: Mouton.

Güler, İlhami. 1997. Kur'an'da Kadın Erkek Eşitsizliğinin Temelleri. İslami Araştırmalar 10: $296-303$.

Güler, İlhami. 2011. Özgürlükçü Teoloji Yazıları. Ankara: Ankara Okulu.

Güler, İlhami. 2015a. Kur'an'ın Ahlak Metafiziği. Ankara: Ankara Okulu.

Güler, İlhami. 2015b. Direniş Teolojisi. Ankara: Ankara Okulu.

Güler, İlhami. 2016a. Kuş Bakışı. Ankara: Ankara Okulu.

Güler, İlhami. 2016b. Realpolitik ve Muhafazakarlik. Ankara: Ankara Okulu.

Güler, İlhami. 2016c. Dine Yeni Yaklaşımlar. Ankara: Ankara Okulu.

Güler, İlhami. 2017a. İsimsiz İlhamlar. Ankara: Ankara Okulu.

Güler, İlhami. 2017b. Sünniliğin Eleştirisine Giriş. Ankara: Ankara Okulu.

Güler, İlhami. 2017c. Sabit Din Dinamik Şeriat. Ankara: Ankara Okulu.

Güler, İlhami. 2017d. İtikaddan İmana. Ankara: Ankara Okulu.

Güler, İlhami. 2018a. Kur'an'ın Mahiyeti ve Yorumu. Ankara: Ankara Okulu.

Güler, İlhami. 2018b. Vicdan Böyle Buyurdu. Ankara: Ankara Okulu.

Güler, İlhami. 2018c. Politik Teoloji Yazıları. Ankara: Ankara Okulu.

Güler, İlhami. 2018d. Aklın İçindeki İlhamlar. Ankara: Ankara Okulu.

Güler, İlhami. 2020. Fazlurrahman'ın Tarihselciliği. Available online: http://www.islamianaliz.com/m/3608/fazlurrahmanintarihselciligi (accessed on 22 February 2020).

Haleem, Abdel Muhammad A. S. 2005. The Quran. Oxford: Oxford University Press.

Hamilton, Paul. 1996. Historicism. London: Routledge.

Ibn Ishaq, Muhammad. 1955. Sirat Rasul Allah [The Life of Muhammad: A Translation of Ibn Ishaq's Sirat Rasul Allah]. Translated by Alfred Guillaume. Oxford: Oxford University Press.

Kamali, Mohammad Hashim. 2019. Crime and Punishment in Islamic Law: A Fresh Interpretation. Oxford: Oxford University Press.

Karaman, Hayreddin, Ali Bardakoğlu, and İbrahim Kafi Dönmez. 1998. İlmihal II. Ankara: Diyanet.

Karaman, Hayrettin, Mustafa Çağrıcı, İbrahim Kafi Dönmez, and Sadrettin Gümüş. 2012. Kur'an Yolu Türkçe Meal ve Tefsiri Vol. II. Ankara: Diyanet İşleri Başkanlığı.

Larkin, Margaret. 1998. The Inimitability of the Quran: Two Perspectives. Religion and Literature 20: 31-47.

Melchert, Christopher. 1997. The Formation of Sunni Schools of Law, 9th-10th Centuries C.E. Brill: Leiden.

Nasir, Jamal J. 1990. The Islamic Law of Personal Status. London: Graham and Trotman.

Nawas, John A. 1996. The Mihna of 218 A. H./833 A. D. Revisited: An Empirical Study. Journal of the American Oriental Society 116: 698-708. [CrossRef]

Neuwirth, Angelika. 2010. Quran and History-A Disputed Relationship. Some Reflections on Quranic History and History in the Quran. Journal of Quranic Studies 5: 1-18.

Özsoy, Ömer. 2004. Kur'an ve Tarihsellik Yazıları. Ankara: Kitabiyat.

Özsoy, Ömer. 2017. Sünnetullah: Bir Kur'an İfadesinin Kavramsallaşması. Ankara: Fecr.

Öztürk, Mustafa, and Hadiye Ünsal. 2018. Kur'an Tarihi. Ankara: Ankara Okulu.

Öztürk, Mustafa. 2013. Kur'an’ı Kendi Tarihinde Okumak: Tefsirde Anakronizme Ret Yazılar. Ankara: Ankara Okulu.

Öztürk, Mustafa. 2014. Tefsir Tarihi Araştırmaları. Ankara: Ankara Okulu. 
Öztürk, Mustafa. 2015a. Kur'an'ın Mu'tezili Yorumu: Ebu Muslim el-İsfehani Örneği. Ankara: Ankara Okulu.

Öztürk, Mustafa. 2015b. Kur'an Dili ve Retoriği. Ankara: Ankara Okulu.

Öztürk, Mustafa. 2015c. Söyleşiler Polemikler. Ankara: Ankara Okulu.

Öztürk, Mustafa. 2016a. Tefsirin Halleri. Ankara: Ankara Okulu.

Öztürk, Mustafa. 2016b. Meal Kültürümüz. Ankara: Ankara Okulu.

Öztürk, Mustafa. 2017a. Kur'an ve Tefsir Kültürümü̈. Ankara: Ankara Okulu.

Öztürk, Mustafa. 2017b. Kur'an, Tefsir ve Usul Üzerine Problemler, Tespitler, Teklifler. Ankara: Ankara Okulu.

Öztürk, Mustafa. 2017c. Cahiliyeden İslamiyet'e Kadın. Ankara: Ankara Okulu.

Öztürk, Mustafa. 2018a. Kur'an ve Tarihsellik Üzerine Çerçeve Yazılar, Örnek Konular. Ankara: Ankara Okulu.

Öztürk, Mustafa. 2018b. Kur'an, Vahiy Nüzul. Ankara: Ankara Okulu.

Öztürk, Mustafa. 2018c. Siyaset İtikad, Din. Ankara: Ankara Okulu.

Öztürk, Mustafa. 2018d. Kadının Boşanma Hakkı Var Mı? Available online: https:/ /www.youtube.com/watch?v=0zQgKo4Kzx4 (accessed on 4 April 2021).

Öztürk, Mustafa. 2019. Kur'an'a Çağdaş Yaklaşımlar. Ankara: Ankara Okulu.

Rahman, Fazlur. 1965. The Concept of Hadd in Islamic Law. Islamic Studies 4: 237-51.

Rahman, Fazlur. 1982. Islam and Modernity Transformation of an Intellectual Tradition. Chicago: The University of Chicago Press.

Rahman, Fazlur. 2009. Major Themes of Quran. Chicago: The University of Chicago Press.

Ricoeur, Paul. 1976. The Interpretation Theory: Discourse and the Surplus of Meaning. Fort Worth: The Texas Christian University Press.

Saeh, Bassam. 2015. The Miraculous Language of the Quran: Evidence of Divine Origin. London: International Institute of Islamic Thought.

Searle, John R. 1969. Speech Acts: An Essay in the Philosophy of Language. Cambridge: Cambridge University Press.

Searle, John R. 1979. Expression and Meaning: Studies in the Theory of Speech Acts. Cambridge: Cambridge University Press.

Simcox, Robin. 2012. Ansar al-Sharia and Governance in Southern Yemen. Current Trends in Islamist Ideology 14: 58-72.

Smith, Barry. 2003. John Searle: From speech acts to social reality. In John Searle. Edited by Barry Smith. Cambridge: Cambridge University Press, pp. 1-33.

Subramanian, Narendra. 2008. Legal Change and Gender Equality: Changes in Muslim Family Law in India. Law E Social Inquiry 33: 631-72. 